\title{
Lehmien laiduntaminen laajentavilla tiloilla - työnmenekki ja käytettävän laidunalan riittävyys
}

\author{
Reetta Palva \\ Työtehoseura, Maatalousosasto, PL 13, 05201 Rajamäki, reetta.palva@tts.fi
}

\section{Johdanto}

Laiduntaminen on yleisin lehmien kesäruokintamuoto Suomessa. Laidunrehu on tuotantokustannukseltaan halvin karkearehu, koska lehmät tekevät korjuutyön. Monet toiminnat navetassa ja pellolla vähenevät laiduntamisen ansiosta. Tavallisesti eläimet käyvät navetassa vain lypsyllä, jolloin samassa yhteydessä jaetaan väkirehu. Ruokinnan osalta jäävät pois säilörehun irrotus siilosta tai paalien purkaminen ja rehun jako ruokintapöydälle. Lannanpoisto- ja kuivitustyötä on vähemmän ja navetan puhtaanapito helpottuu. Navetan peruspesu on helpompi tehdä tyhjässä (tai lähes tyhjässä) navetassa.

Karjakoon kasvaessa edellytykset täysaikaiseen laiduntamiseen saattavat heikentyä, koska tarvittava laidunala lisääntyy ja laidunkäyttöön joudutaan ottamaan kauempana talouskeskuksesta sijaitsevia peltoja. Kuljetusetäisyyden kasvu lisää laiduntamisen työnmenekkiä (Schick 2001). Vaikka karjakoon kasvu toisaalta vähentää lehmää kohti kuluvaa työaikaa, kokonaistyöaika yleensä lisääntyy.

Yksikkökoon kasvu ja sen myötä ruokintateknologian kehitys tulevat muuttamaan karjanhoitotöitä. Uudenaikaiset rehunjakomenetelmät vähentävät ruokinnan työnmenekkiä entisiin pitkälti käsivaraisiin menetelmiin verrattuna. Pihattonavetassa, jossa sekä säilörehun että väkirehun jakaminen on automatisoitu, ruokinnan kokonaistyönmenekki on noin kolmasosa parsinavetan käsityömenetelmiin perustuvasta työnmenekistä 20-30 lehmän kokoisessa karjassa (Kaila 1999). Automatisoidussa ruokinnassa työnmenekki lehmää kohti pienenee edelleen karjakoon kasvaessa. Laidunkaudella työmäärän väheneminen on vastaavasti pienempi.

Tieto laajentamisen vaikutuksesta kesäaikaiseen työnmenekkiin on tärkeää, sillä työnkäyttö voi muodostua laajentavilla tiloilla ongelmaksi. Karjanhoitotöiden osuus on 60-70 \% lypsykarjatilojen töistä, joten niillä on ratkaiseva vaikutus kokonaistyönmenekkiin (Klemola ym. 2000). Työkustannus on myös maidon hinnan jälkeen tärkein maitotilan kannattavuuteen vaikuttava tekijä (Pietola ym. 1998). Lisäksi laajennusinvestointeja suunniteltaessa on tiedettävä tulevat rehunkorjuumäärät, jotta $\mathrm{mm}$. rehuvarastot ja korjuuketjut voidaan mitoittaa oikein.

Suomessa tilusrakenne on usein epäedullinen, koska viljelysmaan osuus maa-alasta on pieni muihin EU-maihin verrattuna (Myyrä 2000). Kannattavuuskirjanpitoaineiston maitotiloilla peruslohkojen keskimääräinen etäisyys tilakeskuksesta on 1,53 km (Myyrä 2001). Keskimääräinen etäisyys ei kuitenkaan kerro käytettävissä olevasta laidunalasta kovin paljon. Toisaalta ei myöskään tiedetä, miten etäällä eläinsuojasta laidun voi sijaita, jotta laiduntaminen vielä on mahdollista.

Suurin osa karjoista vielä laidunnetaan, mutta alueellisia eroja käytännöissä on. Erityisesti Pohjanmaalla laiduntamattomuus on yleistä. Osaksi syynä on epäedullinen tilusrakenne, mutta on myös tiloja, joilla käytännön esteitä ei ole, ja silti laidunnuksesta on luovuttu (Talvilahti 2002). Syynä on saattanut olla muilta saatu esimerkki tai jopa pelko siitä, ettei eläinten käsittelyä vapaana enää hallita.

Vuosien 2003-2004 aikana toteutettavan tutkimuksen tavoitteena on selvittää, miten karjakoon kasvattaminen vaikuttaa laiduntamisen järjestämiseen, kesäajan työnmenekkiin ja laidunnuksen ruokinnalliseen onnistumiseen. Samalla tutkitaan karjatilojen tilusrakenteita niiden merkityksen selvittämiseksi laiduntamisessa. Näin saadaan tietoa laiduntamisen edellytysten muuttumisesta karjakoon kasvaessa ja kokoaikalaidunnusta korvaavien vaihtoehtojen, osittaislaiduntamisen tai jaloittelutarhojen, todennäköisyydestä. Tavoitteena on myös selvittää, onko laiduntamattomuudelle muita syitä mahdollisten laajentumisen mukanaan tuomien ongelmien ohella. 


\section{Aineisto ja menetelmät}

Tutkittaviksi valitaan noin 20, 40 ja 60 lehmän karjoja Pohjois-Savosta ja Keski-Pohjanmaalta, yhteensä 16-18 tilaa. Karjakoon lisäksi vertaillaan myös parsi- ja pihattonavettoja. Tiloilla selvitetään laidunkierron toteutus, tilusrakenteet ja tehdään työaikatutkimuksia. Kesällä 2003 tutkimukseen osallistui kahdeksan tilaa, joilla mitattiin eläinten kuljetukseen käytettyä aikaa sekä lohkojen etäisyyksiä eläinsuojasta. Tilat pitivät kirjaa laidunkierrosta tutkimusta varten. Tutkimuksia jatketaan kesällä 2004, jolloin edellä mainitun lisäksi tullaan tutkimaan laidunten perustamisen ja hoidon työnmenekkiä. Tulosten perusteella laaditaan mallilaskelmat sisä- ja laidunruokinnan työnmenekeistä. Päivittäisten töiden lisäksi lasketaan kesäajan kokonaistyönmenekki, jolloin laskelmassa otetaan huomioon muun muassa säilörehunteon ja lannanlevitystarpeen lisääntyminen sisäruokintatilanteessa.

Tutkimusalueiden tilusrakennetta selvitetään MMM:n peltolohkorekisteristä saatavien tietojen avulla. Peltolohkorekisterissä on olemassa tieto jokaisen peltolohkon linnuntie-etäisyydestä talouskeskukseen. Tutkimustiloilta saadaan myös tieto etäisyydestä lohkoille kulkuteitä pitkin, jolloin näillä tiloilla tehdään myös vertailu linnuntie-etäisyyden ja kuljettavan etäisyyden välillä. Tarkastelemalla tietoja karjakokoluokittain ja vertaamalla niitä tilakohtaisiin tutkimuksiin voidaan tehdä laajempi arvio tilojen edellytyksistä onnistuneelle laiduntamiselle.

Laiduntamisen ruokinnallista onnistumista tutkimustiloilla arvioidaan MTT:ssa kehitetyn Maitoisa-mallin avulla, jolla voidaan laskea koelypsyjen perusteella karjalle ns. kuukausiratkaisuja, jotka kuvaavat karjan ruokinnan ja hoidon tasoa (Nousiainen 2002). Lisäksi selvitetään laiduntamattomuuden syitä kirjekyselyllä tiloille, joilla lehmät pidetään sisällä ympäri vuoden. Syiden kartoitus mahdollistaa tutkimuksen ja neuvonnan ohjaamisen havaittuihin ongelmiin.

Tutkimus on osa MTT Pohjois-Savon tutkimusaseman vetämää laajentavien karjatilojen kesäruokintavaihtoehdot -tutkimusta, jossa mukana ovat myös Kuopion yliopiston Soveltavan biotekniikan instituutti sekä MTT taloustutkimus, MTT eläinravitsemus sekä Seinäjoen ja Pohjois-Savon ammattikorkeakoulut.

\section{Kirjallisuus:}

Kaila, E. 1999. Lypsykarjan hoitotöiden taloudellinen koneellistaminen. Työtehoseuran monisteita $72.49 \mathrm{~s}$.

Klemola, E., Pihamaa, P. ja Heikkilä A-M. 2000. Laajentavan lypsykarjatilan tuotannon ja työnkäytön suunnittelu. Työtehoseuran julkaisuja 375. $88 \mathrm{~s}$.

Klemola, E., Kaila, E., Karttunen, J., Laaksonen, K. ja Kirkkari, A-M. 2002. Lohkon koon ja muodon vaikutukset työaikaan. Työtehoseuran maataloustiedote $545.6 \mathrm{~s}$.

Myyrä, S. 2000. Maatilojen tilusrakenne. Maatalouden taloudellisen tutkimuslaitoksen selvityksiä $3.47 \mathrm{~s}$.

Myyrä, S. 2001. Tilusrakenteen taloudelliset vaikutukset. Maatalouden taloudellisen tutkimuslaitoksen selvityksiä $1.30 \mathrm{~s}$.

Nousiainen, J. 2002. MAITOISA-sovellus, apu maidontuotantotilojen tuotannon ohjaukseen. Julkaisussa: Maataloustieteenpäivät 2002. [verkkojulkaisu]. Suomen Maataloustieteellisen seuran julkaisuja no 18. Toim. Anneli Hopponen. Viitattu 10.12.2003. Julkaistu 1.1.2002. Saatavilla Internetissä: http://www.agronet.fi/maataloustieteellinenseura/julkaisut/esit/48nousiainen.pdf.

Pietola, K., Lempiö, P. ja Heikkilä, A-M. 1998. Kotieläinrakennusinvestointien kannattavuus ja maksuvalmius. Maatalouden taloudellisen tutkimuslaitoksen tutkimuksia $229.118 \mathrm{~s}$.

Schick, M. 2001. Weidehaltung Milchvieh. Zeitbedarf, Arbeitsorganisation und Vergleich mit Eingrasfahren. FAT-Berichte 562. Tänikon. $8 \mathrm{~s}$.

Talvilahti, A. 2002. Kotieläinagronomi, Etelä-Pohjanmaan Maaseutukeskus. Laiduntamattomuuden syyt Pohjanmaalla. Suullinen tiedonanto. 